\title{
Limnocalanus macrurus in the Kara Sea (Arctic Ocean): an opportunistic copepod as evident from distribution and lipid patterns
}

Received: 13 March 2003/ Accepted: 28 July 2003 / Published online: 5 September 2003

(C) Springer-Verlag 2003

\begin{abstract}
Limnocalanus macrurus is an important member of the zooplankton communities of the Siberian shelf seas. During the cruise, Boris Petrov 1999, in August/ September to the southern Kara Sea and the $\mathrm{Ob}$ and Yenisej estuaries, its abundance and vertical distribution were investigated. In adults, salinity tolerance, egg production, feeding and lipid composition were studied. L. macrurus occurred in water with salinities ranging from 1.7 to $>33$ without clear preference, as revealed from salinity-tolerance experiments. The dominance of adults and their high wax-ester content, as well as the lack of egg production and feeding activity, suggest that the population was in the pre-overwintering condition. Wax esters allow L. macrurus to survive long starvation periods and to reproduce in times of little food availability, but through its potential carnivory, it should be able to replenish its diet by preying on other zooplankton. Morphology and swimming behaviour of L. macrurus resemble the omnivorous copepod Metridia longa, which, however, is mainly found in the open ocean. The overall lipid composition and the mode of lipid storage also point to an omnivorous feeding behaviour. However, the high proportion of the marker fatty acid 16:1(n-7) suggests that L. macrurus strongly exploited the existent phytoplankton bloom, consisting mainly of diatoms. A striking characteristic of its lipids is the high level of the 20:1(n-7) fatty alcohol in addition to the 18:1(n-7) fatty acid and alcohol. It is the first copepod species known to produce such high amounts of 20:1(n-7) alcohol. Since this alcohol and the corresponding fatty acid are not abundant in any prey, this long-chain monounsaturated wax-ester moiety has to be produced de novo. Owing to these particular lipid characteristics in its distribution, feeding, and life-cycle
\end{abstract}

H.-J. Hirche $(\bowtie) \cdot$ I. Fetzer · M. Graeve $\cdot$ G. Kattner Alfred Wegener Institute for Polar and Marine Research, Postfach 1201 61, 27515 Bremerhaven, Germany

E-mail: hhirche@awi-bremerhaven.de

Tel.: + 49-471-48311336

Fax: $+49-471-48311149$ strategy, L. macrurus can be described as a very versatile and opportunistic copepod.

\section{Introduction}

The calanoid copepod Limnocalanus macrurus was originally described as a relict freshwater species (Sars 1903), but it seems to have a wide range of osmotic tolerance. It is reported from many cold and deep freshwater lakes of the northern hemisphere, but is also quite common in the Arctic coastal waters of Canada, Russia and Alaska (Roff and Carter 1972; Bowman and Long 1973; Løvik 1979; Vanderploeg et al. 1998). Single populations are also found in the Baltic and Caspian Seas (Holmquist 1970).

In the Laptev and Kara Seas, it is a dominant component of the zooplankton communities (Vinogradov et al. 1995a, 1995b; Lischka et al. 2001; Fetzer et al. 2002). These shelf seas are characterized by an extreme seasonality of freshwater inflow through Siberian rivers. In early summer, a large plume of low-saline water spreads out on top of oceanic water, extending the brackish-water region far away from the river mouths. The marine distribution of $L$. macrurus seems to be closely related to freshwater admixture, since it is found only rarely on the shelf break of the Laptev and Kara Seas and is absent in the Barents Sea and the Arctic Ocean proper (Kosobokova et al. 1998; Kosobokova and Hirche 2000). In the light of increasing river discharge to the Arctic Ocean (Peterson et al. 2002), the habitat of $L$. macrurus may be extended in the future.

Complete studies of the life-cycle of $L$. macrurus are only available from freshwater lakes. In Lake Michigan, the reproductive period lasts from November to May and seems to be timed so that the new generation develops in spring during high abundance of prey, which consists of crustacean microzooplankton and net phytoplankton (Vanderploeg et al. 1998). A similar life-cycle was described for L. macrurus in a high-Arctic lake by Roff and Carter (1972), where first nauplii appeared at the beginning of December. However, in Resolute Lake, 
the reproductive phase was shifted by as much as 6 months (Roff 1972).

Survival of long periods of unfavourable food conditions and reproduction in the winter is made possible by a large lipid content in autumn, which accounted for up to $67 \%$ dry mass in L. macrurus (Vanderploeg et al. 1998). In Lake Michigan, Cavaletto et al. (1989) found wax esters to contribute $57-80 \%$ to total lipids, similar to many highlatitude herbivorous Calanus species. Accordingly, Vanderploeg et al. (1998) suggested that L. macrurus retained a marine Arctic lipid and life-cycle strategy. It is considered an omnivore with a strong carnivorous tendency. Predation on nauplii and copepodites (C) starts when it becomes a CIV (Warren 1985). In a lake on northern Ellesmere Island, van Hove et al. (2001) reported adult L. macrurus preying upon the smaller copepod Drepanopus bungei.

Detailed fatty-acid and alcohol compositions have been used to determine trophic relationships and to identify feeding behaviour and food preferences of zooplankton species (e.g. Falk-Petersen et al. 1990; Graeve et al. 1994a). This approach has a high potential since dietary fatty acids from primary producers are conserved and incorporated into lipids by copepods. However, copepods are also themselves important producers of particular fatty acids and alcohols (reviewed by Sargent and Henderson 1986; Dalsgaard et al. 2003). Fatty acids and alcohols of L. macrurus have not hitherto been determined.
Here we present data on the distribution, population structure, egg production and lipid pattern of L. macrurus in the Kara Sea collected in September 1999. In order to understand the mechanisms controlling the distribution of this euryhaline species in the estuarine and marine environment of Arctic marginal seas, experiments of salinity tolerance were conducted. The fatty-acid and alcohol composition will help to elucidate life-cycle and feeding strategies.

\section{Materials and methods}

Sampling

Samples were collected at 24 stations during a cruise with RV "Akademik Boris Petrov" from 26 August to 9 September 1999 to the southern Kara Sea (Fig 1). For zooplankton sampling, a Nansen closing net was used $\left(0.442 \mathrm{~m}^{2}\right.$ catching area, $150 \mu \mathrm{m}$ mesh size; $0.5 \mathrm{~m} \mathrm{~s}^{-1}$ hauling speed) below and above the pycnocline, which was determined from CTD profiles. At shallow stations $(<10 \mathrm{~m}$ depth) in the $\mathrm{Ob}$ and Yenisej estuaries, the net frame was mounted with a non-closing, short net of $1 \mathrm{~m}$ length. For determination of distribution and abundance, samples were preserved in $4 \%$ boraxbuffered formaline. All specimens were counted.

\section{Salinity tolerance}

Two salinity-tolerance experiments with L. macrurus were set up directly on board after collection. In each experiment, a complete Nansen-net tow was split into nine parts and incubated in Plexiglas
Fig. 1a-d Distribution of salinity and abundance of Limnocalanus macrurus in the Kara Sea. Surface (a) and bottom (b) salinity; abundance of L. macrurus in top (c) and bottom layer (d). Station numbers are given in the surface salinity plot

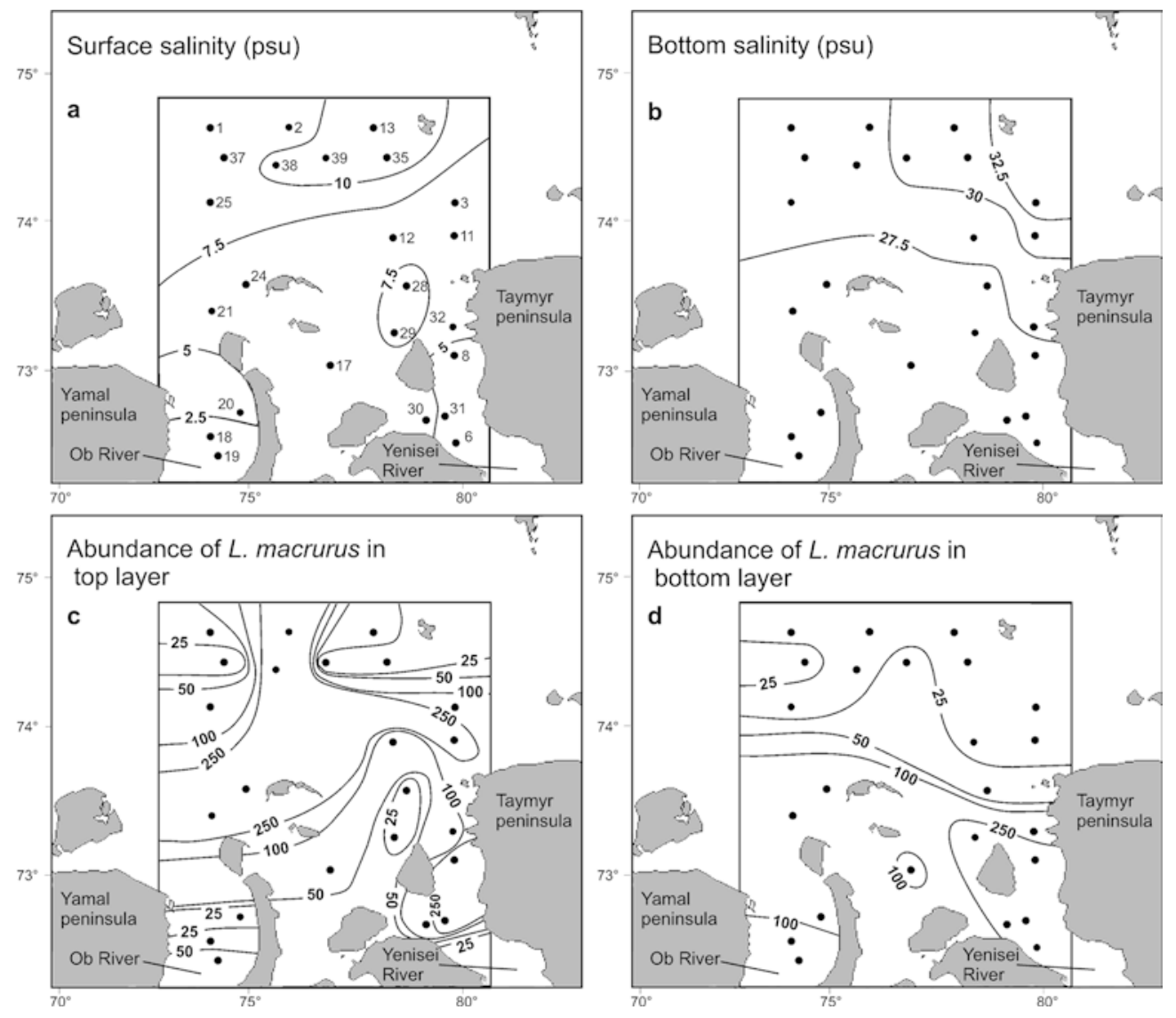


cylinders with mesh $(330 \mu \mathrm{m})$ false bottoms. Cylinders were then suspended in 3-1 poly-methyl-pentene beakers containing filtered seawater from the site of collection. During one experiment with samples from sts. 11 and 13, salinity was increased every $24 \mathrm{~h}$ by 5 psu starting from 10 up to 40 . The second experiment with samples from st. 29 started at a salinity of 20 . Every $24 \mathrm{~h}$ in one half of the beakers, salinity was increased in steps of 5 psu from 20 to 40 , whereas in the other half, salinity was decreased by 5 psu from 20 to zero. Dead specimens were counted and removed every day. The rest were transferred with the Plexiglas cylinders to fresh seawater with adjusted salinity. Specimens in three beakers were used as controls, with constant salinities of 10 and 20, respectively. Dead specimens in the controls were counted and subtracted from the experimental data.

\section{Feeding experiments}

Feeding experiments with L. macrurus were carried out on board and, in addition, specimens were transported to the home laboratory in Bremerhaven. There, about 1 month after collection, feeding experiments were set up again using mixed phytoplankton cultures grown from Kara Sea inoculates and nauplii of Artemia salina. Single female L. macrurus were incubated in $10-\mathrm{ml}$ cell wells at $4^{\circ} \mathrm{C}$ (according to the in-situ temperature) with a dense culture of phytoplankton, containing mainly the brackish-water diatoms Asterionella formosa and Cyclotella sp. from the same waters as the copepods (Larionov and Kodina 2000). After $24 \mathrm{~h}$, the wells were inspected for faecal pellets. In a second experiment, ten Artemia nauplii were added to one female in each cell well. In addition, one experiment was set up with 50 females incubated in 21 of filtered seawater containing 50 nauplii. Due to the low temperatures, the nauplii were sinking to the bottom after several hours. After $24 \mathrm{~h}$, the water was filtered over a 50- $\mu \mathrm{m}$ sieve and searched for faecal pellets.

Egg production

For egg-production measurements, 42-48 females of L. macrurus were sorted directly after capture. Single females were incubated in cell wells containing $10 \mathrm{ml}$ filtered seawater at in-situ temperature in dim light for $24 \mathrm{~h}$. Cell wells were checked for eggs usually every $3 \mathrm{~h}$ to account for cannibalism. At 1 station, in addition, 100 females were incubated in Plexiglas cylinders with mesh $(330-\mu \mathrm{m})$ false bottoms to separate eggs from females. Cylinders were suspended in 3-1 poly-methyl-pentene beakers containing filtered seawater.

\section{Dry mass and lipids}

Ten to 15 L. macrurus (total number of samples: 8 for females, 9 for males, 3 for $\mathrm{CV}$ ) were sorted into pre-weighed aluminium trays and stored at $-20^{\circ} \mathrm{C}$. In the laboratory, they were dried at $60^{\circ} \mathrm{C}$ for $24 \mathrm{~h}$ and weighed on a microbalance.

Two samples of females and 1 of males (20 individuals each) were sorted at sts 11 and 13 immediately after collection and preserved in dichloromethane:methanol (2:1, by volume). Samples were stored at $-30^{\circ} \mathrm{C}$ until analysis. Lipids were extracted essentially according to the method of Folch et al. (1957). The fatty-acid and alcohol compositions were determined by gas chromatography (Kattner and Fricke 1986). Lipids were hydrolysed in methanol containing 3\% concentrated sulphuric acid, and fatty acids were converted to methyl esters by transesterification at $80^{\circ} \mathrm{C}$ for $4 \mathrm{~h}$. Fatty-acid methyl esters and free alcohols were then simultaneously analysed with a gas liquid chromatograph (Chrompack 9000) on a $30 \mathrm{~m} \times 0.25 \mathrm{~mm}$ i.d. wall-coated open tubular column (film thickness: $0.25 \mu \mathrm{m}$; liquid phase: DB-FFAP) using temperature programming. Fatty acids and alcohols were identified with standard mixtures and, if necessary, additional confirmation was carried out by GC-MS. The structure of the alcohols, especially 20:1(n-7), was additionally determined by GC-MS after thin-layer chromatographic separation from fatty-acid methyl esters on silica gel (Kattner et al. 1998). The proportion of wax esters of total lipid was calculated according to their molecular structure using the areas of the fatty acids and alcohols as obtained by GC analysis (Kattner and Krause 1987).

\section{Results}

\section{Hydrography}

A general description of the hydrographic conditions and zooplankton community during this study was published previously (Amon and Köhler 2000; Stephansev and Shmelkov 2000; Fetzer et al. 2002). Therefore the hydrography is only briefly described here. The depth range of the 24 stations varied from a maximum of $38 \mathrm{~m}$ (st. 39) in the central part of the Kara Sea to $5 \mathrm{~m}$ (st. 6) in the inner estuary of the Yenisej River. Surface salinity in the inner parts of $\mathrm{Ob}$ Bay had a minimum value of almost 2 , which slowly increased to 10 towards the outer parts, and at the southernmost station in the Yenisej River, salinity was 2.7. Surface temperature ranged from 3.5 to $7^{\circ} \mathrm{C}$ in both rivers and their estuaries. At the northernmost stations, where the influence of the colder marine water masses became more dominant, the surface temperature decreased to $2.9^{\circ} \mathrm{C}$. The bottom temperatures showed constant values between $0^{\circ}$ and $1.9^{\circ} \mathrm{C}$. A strong pycnocline, which was located between 5 and $13 \mathrm{~m}$ depth with an average thickness of about $3 \mathrm{~m}$, separated the low saline waters from the deeper oceanic layer that reached far into the rivers below the pycnocline. The sea ice in the Kara Sea starts to break up in June (Blanchet et al. 1995). During our cruise, the sea was completely free of ice. River runoff exhibits a large seasonal signal, with the maximum discharge occurring usually in June (Pavlov and Pfirman 1995).

\section{Abundance and distribution}

L. macrurus was among the most abundant copepods of the zooplankton population (mean 10.6\%) in the study area. It was present at $96 \%$ of all stations. At sts. 13 and 38 , it contributed $30 \%$ of total zooplankton abundance. Maximum concentration was 5,990 individuals $\mathrm{m}^{-3}$ (st. 8). The population was dominated by adults, with females more abundant than males; copepodites $\mathrm{V}$ made up $6.3 \%$; younger CI-CIV were found only at a very low percentage (Table 1) at five stations in Ob Bay and north of it (sts. 18, 19, 20, 21, 24). No eggs were produced during egg-production experiments, explaining the lack of nauplii and young copepodites. However, female gonads were well developed.

Females probably did not feed anymore during this late sampling season, as shown by the feeding experiments in which females did not produce faecal pellets. However, specimens were actively swimming in their containers. 
Table 1 Limnocalanus macrurus in the Kara Sea. Stage composition as percent of all stages (mean of all stations) and dry mass (mean and standard deviation, SD)

\begin{tabular}{lll}
\hline Stage & $\begin{array}{l}\text { Stage composition } \\
\%\end{array}$ & $\begin{array}{l}\text { Dry mass }(\mu \mathrm{g}) \\
\text { Mean } \pm \mathrm{SD}\end{array}$ \\
\hline C I & 0.2 & \\
C II & 0.2 & \\
C III & 0.2 & $83 \pm 72$ \\
C IV & 0.2 & $193 \pm 65$ \\
C V & 6.3 & $147 \pm 35$ \\
Female & 54.5 & \\
Male & 38.6 & \\
\hline
\end{tabular}

The distribution patterns of L. macrurus above and below the pycnocline and the surface and bottom salinities are presented in Fig. 1. This species was found over a wide salinity range from 1.7 to 33.3 . The surface abundance maxima (Fig. 1c) in the north were in close areas to minima. Thus, at st. 38 we found 317 ind. $\mathrm{m}^{-3}$ as opposed to 5 ind. $\mathrm{m}^{-3}$ at st. 37 and 3 ind. $\mathrm{m}^{-3}$ at st. 39. Distribution in the bottom layer (Fig. 1d) was less variable than in the top layer. From the abundance maxima at sts. 29 and 8 in the wake of the Yenisej River, abundances decreased rapidly towards the north. Similarly, in the eastern part, higher numbers in the outer estuary of the $\mathrm{Ob}$ River decreased sharply to the north around $74^{\circ} \mathrm{N}$.

In the abundance of L. macrurus, there was no clear trend in any of the water layers, although it seems that the species is less abundant at the lowest and highest salinities (Fig 2). Regarding vertical distribution, L. macrurus was more abundant in the upper layer at 11 stations and more in the deep layer at 7 stations (Fig. 3). At 3 stations abundance was similar, and at 5 stations $(2,11,13,29,38)$ differences in vertical distribution were enormous, with several hundred specimens in one layer and almost none in the other. Thus, 507 ind. $\mathrm{m}^{-3}$ in the upper layer contrasted with 13.6 in the lower layer at st. 29. Stations with maxima in the upper or lower layer were sometimes closely spaced, e.g. st. 39 (maximum in

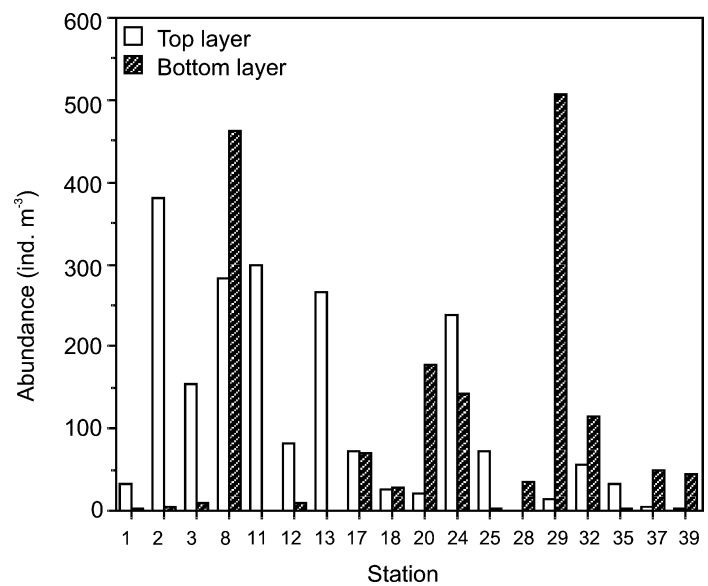

Fig. 2 Vertical distribution of Limnocalanus macrurus from stations with vertically separated hauls

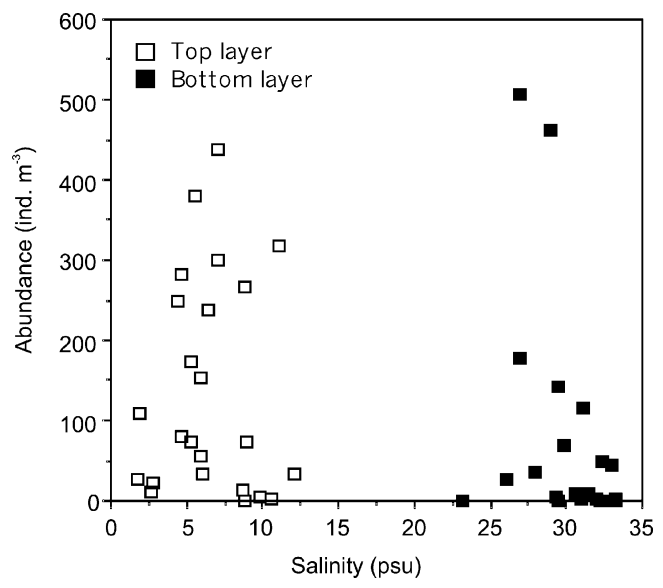

Fig. 3 Abundance of Limnocalanus macrurus from two layers versus salinity of surface and bottom waters

lower layer) and st. 38 (maximum in upper layer). Therefore, no clear spatial trend with regard to these extreme stations could be detected.

\section{Salinity tolerance}

According to its distribution pattern described above, L. macrurus is a euryhaline species. All males and females collected at a salinity of 10 survived successive increase of salinity in steps of 5 until 40 (Fig 4a). In contrast, $40 \%$ of the specimens collected at a salinity of 20 died at 40 (Fig. 4b). At decreasing salinity, mortality increased abruptly between 5 and 0 . As L. macrurus was also found, although in low numbers, at stations with salinities down to 1.7 , the lower salinity limit seems to be

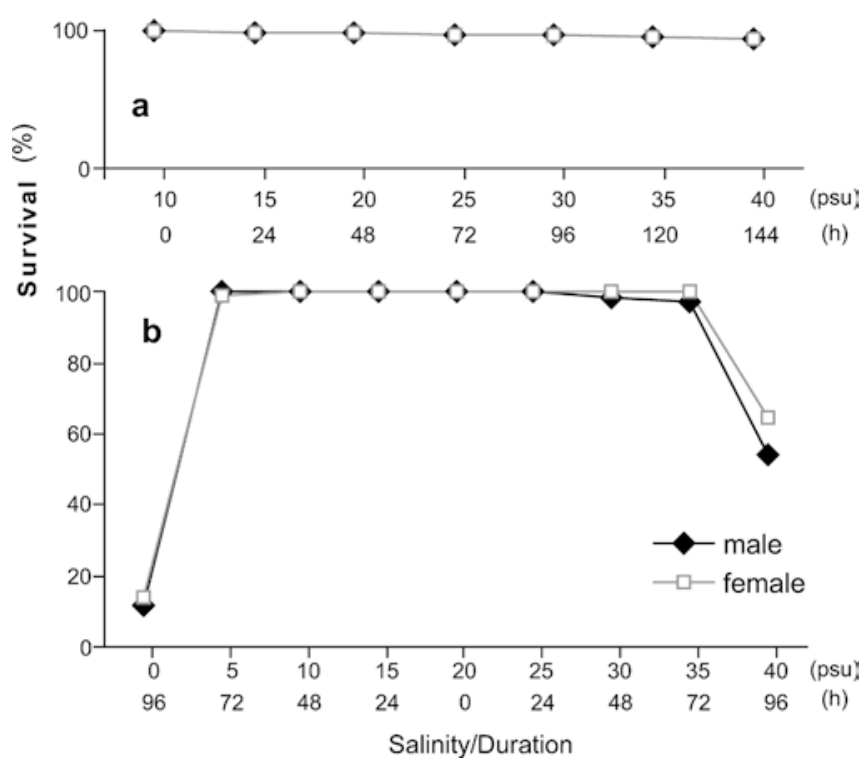

Fig. 4a, b Survival rate of adult Limnocalanus macrurus collected at 10 psu at increasing salinities (a) and collected at 20 psu at increasing and decreasing salinites (b) 
close to zero. At st. 6 with the lowest overall salinity in the whole water column (surface 2.6 and bottom 3.0), 10.4 ind $\mathrm{m}^{-3}$ were counted, and at st. 18 (surface 1.7 and bottom 26.1) 25 ind. $\mathrm{m}^{-3}$.

Dry mass and lipid composition

The dry mass of adults and CV L. macrurus is given in Table 1. Females had the highest dry mass, ranging from 102 to $295 \mu \mathrm{g}$ (mean of $193 \mu \mathrm{g}$ ). The dry mass of males was slightly lower $(92-186 \mu \mathrm{g})$, being $147 \mu \mathrm{g}$ on average. CV stages had only half of the mass of adults (mean of $83 \mu \mathrm{g}$ ).

The fatty-acid and alcohol compositions were determined for females and males. The proportions of wax esters and fatty acids/alcohols were very similar in both sexes, and therefore in Table 2 only mean values are presented. The lipids of $L$. macrurus were dominated by wax esters, accounting on average for $87.1 \%$ of total lipid. Major fatty acids were 16:1(n-7), the 18:1 isomers $(n-9)$ and $(n-7), 20: 5(n-3)$ and 22:6(n-3), composing $72 \%$

Table 2 Limnocalanus macrurus in the Kara Sea. Fatty-acid and alcohol composition [mass \% of total fatty acids and alcohols, respectively; mean and standard deviation $S D$, number of samples (in parentheses) and wax-ester proportion in \% of total lipid]

\begin{tabular}{ll}
\hline Fatty acids & Mean \pm SD (3) \\
\hline $14: 0$ & $0.8 \pm 0.2$ \\
$15: 0$ & $0.0 \pm 0.1$ \\
$16: 0$ & $4.3 \pm 0.9$ \\
$16: 1(n-7)$ & $19.6 \pm 1.9$ \\
$16: 1(n-5)$ & $0.4 \pm 0.2$ \\
$16: 2(n-4)$ & $0.5 \pm 0.4$ \\
$16: 3(n-4)$ & $0.3 \pm 0.2$ \\
$16: 4(n-1)$ & $0.1 \pm 0.1$ \\
$18: 0$ & $0.5 \pm 0.3$ \\
$18: 1(n-9)$ & $16.2 \pm 1.6$ \\
$18: 1(n-7)$ & $12.6 \pm 1.1$ \\
$18: 2(n-6)$ & $2.2 \pm 0.5$ \\
$18: 3(n-3)$ & $1.1 \pm 0.2$ \\
$18: 4(n-3)$ & $2.3 \pm 0.2$ \\
$20: 1(n-9)$ & $4.2 \pm 0.4$ \\
$20: 1(n-7)$ & $1.4 \pm 0.2$ \\
$20: 4(n-6)$ & $1.4 \pm 0.1$ \\
$20: 4(n-3)$ & $3.8 \pm 0.2$ \\
$20: 5(n-3)$ & $12.9 \pm 2.3$ \\
$22: 1(n-11)$ & $0.5 \pm 0.4$ \\
$22: 1(n-9)$ & $0.3 \pm 0.3$ \\
$22: 1(n-7)$ & $0.3 \pm 0.1$ \\
$22: 5(n-3)$ & $2.4 \pm 0.3$ \\
$22: 6(n-3)$ & $10.7 \pm 1.8$ \\
$24: 1$ & $1.3 \pm 0.2$ \\
Alcohols & \\
$14: 0$ & $14.3 \pm 3.2$ \\
$16: 0$ & $48.6 \pm 1.0$ \\
$16: 1(n-7)$ & $3.3 \pm 0.4$ \\
$18: 1(n-9)$ & $3.0 \pm 0.3$ \\
$18: 1(n-7)$ & $13.7 \pm 1.2$ \\
$20: 1(n-9)$ & $2.4 \pm 0.6$ \\
$20: 1(n-7)$ & $13.1 \pm 2.3$ \\
$22: 1(n-11)$ & $1.5 \pm 0.3$ \\
Wax ester proportion of total lipid & $87.1 \pm 2.3$ \\
\hline & \\
\hline &
\end{tabular}

of total fatty acids. Minor components were 16:0, 20:1(n-9), 20:4(n-3), 22:5(n-3), 18:4(n-3) and 18:2(n-6). The alcohols were dominated by 16:0, accounting for half of the total. Significant proportions with more than $10 \%$ were detected for $14: 0,18: 1(n-7)$ and $20: 1(n-7)$ alcohols. The fatty acids and alcohols of the $(n-7)$ family with 16-20 carbon atoms contributed high proportions (ca. 30\%) to the total fatty acids and alcohols, respectively.

\section{Discussion}

During our study in the southern Kara Sea, L. macrurus was present at all but one station, and made up on average $10.6 \%$ of total zooplankton abundance. At some stations it reached up to $30 \%$. Similarly, in the very shallow part of the Laptev Sea close to the rivers Lena and Yana, it also built the bulk of zooplankton abundance and biomass (up to 64\% total biomass; Lischka et al. 2001). Regional distribution patterns and salinity tolerance experiments could not provide a clear picture of the factors controlling its distribution. Although it is assumed to be a brackish-water species (Vinogradov et al. 1995a, 1995b; Lischka et al. 2001), it was found in this study at many stations with high oceanic salinities. We also could not detect any trend in the vertical distribution. Interannual variability is strikingly high; thus, in 1997 L. macrurus accounted for only $0.5 \%$ of total zooplankton in samples collected in the same area at a similar time of year (Fetzer et al. 2002).

The predominance of adults indicates that the population is close to its overwintering state. Abramova (1999) described the overwintering population in the Laptev Sea as consisting only of adults, similar to lake populations (Vanderploeg et al. 1998). In contrast to many other polar species, the new generation moves through all copepodite stages to adult without diapausing (Vanderploeg et al. 1998). The preparation for overwintering is also indicated by the enormous lipid content of the adults. Seasonal variation in lipid classes of L. macrurus from Lake Michigan has been determined by Cavaletto et al. (1989) and Vanderploeg et al. (1998). They found large stores of lipids (67\% dry mass) and wax esters constituting $10-80 \%$ of total lipids. Total lipids, wax esters and oil sac continued to build in the adults throughout the summer and autumn until the maximum was reached before reproduction in winter (Vanderploeg et al. 1998). Their observations correlate well with the high wax-ester content in adults collected in September during our study.

The high wax-ester content of L. macrurus is similar to many herbivorous calanoid copepods (e.g. Lee 1975; Sargent and Henderson 1986; Kattner and Hagen 1995). Wax esters are important energy-storage compounds, which enable copepods to survive long periods of starvation and provide energy for reproduction. L. macrurus follows a similar reproductive strategy to 
Calanus hyperboreus and $C$. glacialis in the Arctic Ocean and on Arctic shelves, which spawn in winter (Sars 1903; Conover 1988; Hirche and Kattner 1993; Hirche and Niehoff 1996). With regard to lipid accumulation and composition, C. hyperboreus seems to be best adapted to the extreme Arctic environment. It has the highest lipid content and highest proportions of wax esters with the most energy-rich moieties, i.e. high amounts of long-chain monounsaturated fatty acids and alcohols with 20 and 22 carbon atoms (Albers et al. 1996). C. glacialis contains less lipids of high caloric value, but still more than $L$. macrurus. The lipid composition of $L$. macrurus is, however, more similar to omnivorous copepods like Metridia longa or Rhincalanus gigas (Graeve et al. 1994a; Albers et al. 1996), due to shorter-chain lipid moieties dominated by 14,16 and 18 carbon chain length, and especially by the alcohols 14:0 and 16:0. Another difference from C. glacialis is the structure of the oil sac, which in the Calanus species is one structure extending over the whole cephalothorax, whereas in L. macrurus four oil sacs surround the intestines (Vanderploeg et al. 1998). While many Calanus species spend the winter in a diapause as described by Hirche (1996, 1997), the physiological state of L. macrurus during winter has not yet been described. Lipids are drawn down to extremely low levels $(10 \%)$ during the reproductive period in winter (Vanderploeg et al. 1998), but this does not exclude food uptake. For a carnivore or omnivore that preys on items as large as diaptomid copepodites (Warren 1985), food should be available all winter long. However, in our preliminary feeding experiments, females were not feeding on phytoplankton or Artemia nauplii in autumn, although they kept on cruising continuously.

In our adult $L$. macrurus, the high level of fatty acids and alcohols of the (n-7) family with 16-20 carbon atoms is striking. High proportions of the 16:1(n-7) fatty acid are well documented in marine herbivorous copepods, especially in the high-Arctic C. glacialis (e.g. Tande and Henderson 1988; Hirche and Kattner 1993; Scott et al. 2002). These high levels are attributed to feeding on diatoms, which are extremely rich in this fatty acid (e.g. Kates and Volcani 1966; Ackman et al. 1968; Graeve et al. 1994b). During our study, a phytoplankton bloom covered large parts of the southern Kara Sea, with a high proportion of diatoms (Larionov and Kodina 2000; Deubel et al. 2003). Obviously, L. macrurus had used these diatoms, although it was described as an omnivore with a tendency to carnivory (Vanderploeg et al. 1998). Alternatively, the 16:1(n-7) fatty acid could originate from feeding on herbivorous copepods rich in this fatty acid due to grazing on diatoms (Tande and Henderson 1988; Kattner et al. 1989). L. macrurus further elongates 16:1(n-7) to 18:1(n-7) and 20:1(n-7) fatty acids and, by reduction, to its major monounsaturated fatty alcohols (Table 2). This two-step elongation to $20: 1(n-7)$ is exceptional. L. macrurus is the first copepod species known to produce such high amounts of 20:1(n-7) alcohol. In addition, the high proportions of the 18:1(n-7) fatty acid and alcohol are also unusual.

The overall lipid composition of L. macrurus points to an omnivorous feeding behaviour comparable to another Arctic copepod, M. longa. The fatty-acid and alcohol composition of that species is characterized by short-chain moieties but it contains less wax esters. Significant amounts of the long-chain monounsaturated fatty acids and alcohols, 20:1(n-9) and 22:1(n-11), in $M$. longa were attributed to feeding on herbivorous calanids rich in these components. This is a major difference from L. macrurus, which contains considerable amounts of the 20:1(n-7) alcohol. This alcohol and the corresponding fatty acid are non-existent or only trace components in most marine organisms studied so far. Thus, they are most likely produced by L. macrurus and therefore imply herbivory. Not only the habitus and feeding patterns but also the mode of lipid storage suggest that L. macrurus occupies an intermediate position between typical omnivorous and herbivorous species. Owing to this adaptation, L. macrurus is one of the more opportunistic and versatile marine and freshwater copepods.

Acknowledgements We thank the captain and crew of RV "Akademik Boris Petrov" for support during the cruise. We are grateful to M. Stürcken for lipid analyses, and E. Kolosova for counting zooplankton samples; L. Stephantsev and B. Shmelkov provided CTD data and E.-M. Nöthig information on phytoplankton. H.J.H. and I.F. were supported through the BMBF 03G0539A1, Project Siberian River Runoff (SIRRO).

\section{References}

Abramova EN (1999) Composition, abundance and population structure of spring-time zooplankton in the shelf-zone of Laptev Sea. In: Kassens H, Bauch HA, Dmitrenke IA, Eicken H, Hubberten H-W, Melles M, Thiede J, Timokhov LA (eds) Land-ocean systems in the Siberian Arctic. Springer, Berlin Heidelberg New York, pp 161-168

Ackman RG, Tocher CS, McLachlan J (1968) Marine phytoplankter fatty acids. J Fish Res Board Can 25:1603-1620

Albers CS, Kattner G, Hagen W (1996) The compositions of wax esters, triacylglycerols and phospholipids in Arctic and Antarctic copepods: evidence of energetic adaptations. Mar Chem $55: 347-358$

Amon R, Köhler H (2000) Distribution of surface-water salinity. In: Stein R, Stephanets O (eds) Scientific cruise report of the joint Russian-German Kara Sea expedition of RV 'Akademik Boris Petrov' in 1999. Ber Polarforsch 360:20-21

Blanchet D, Wilkman G, Golovin N, De Franco S (1995) Ice expedition in the Kara Sea in 1993. Proceedings of the second international conference on the development of the Russian Arctic offshore (RAO-95). St. Petersburg

Bowman TE, Long A (1973) Relict populations of Drepanopus bungei and Limnocalanus macrurus grimaldii (Copepoda: Calanoida) from Ellesmere Island, N.W.T. Arctic 21:173-180

Cavaletto JF, Vanderploeg HA, Gardner WS (1989) Wax esters in two species of fresh water zooplankton. Limnol Oceanogr 34:785-789

Conover RJ (1988) Comparative life histories in the genera Calanus and Neocalanus in high latitudes of the northern hemisphere. Hydrobiologia 167/168:127-142 
Dalsgaard J, St. John M, Kattner G, Müller-Navarra D, Hagen W (2003) Fatty acid trophic markers in the pelagic marine environment: a review. Adv Mar Biol (in press)

Deubel H, Engel M, Fetzer I, Gagaev S, Hirche HJ, Klages M, Larionov V, Lubin P, Lubina O, Nöthig E-M, Odkolodkov Y, Rachor E (2003) The Kara Sea ecosystem: phytoplankton, zooplankton and benthos communities influenced by river runoff. Proc Mar Sci (in press)

Falk-Petersen S, Hopkins CCE, Sargent JR (1990) Trophic relationships in the pelagic, Arctic food web. In: Barnes M, Gibson RN (eds) Trophic relationships in marine environments. Proceedings of the 24th European Marine Biology Symposium, Oban, Scotland. Aberdeen University Press, pp 315-333

Fetzer I, Hirche HJ, Kolosova EG (2002) The influence of freshwater discharge on the distribution of zooplankton in the southern Kara Sea. Polar Biol 25:404-415

Folch J, Lees M, Sloane-Stanley GH (1957) A simple method for the isolation and purification of total lipides from animal tissues. J Biol Chem 226:497-509

Graeve M, Hagen W, Kattner G (1994a) Herbivorous or omnivorous? On the significance of lipid compositions as trophic markers in Antarctic copepods. Deep Sea Res 41:915-924

Graeve M, Kattner G, Hagen W (1994b) Diet-induced changes in the fatty acid composition of Arctic herbivorous copepods: experimental evidence of trophic markers. J Exp Mar Biol Ecol $182: 97-110$

Hirche HJ (1996) Diapause in the marine copepod Calanus finmarchicus. Ophelia 44:129-143

Hirche HJ (1997) Life cycle of the copepod Calanus hyperboreus in the Greenland Sea. Mar Biol 128:607-618

Hirche HJ, Kattner G (1993) Egg production and lipid content of Calanus glacialis in spring: indication of a food-dependent and food-independent reproductive mode. Mar Biol 117:615-622

Hirche HJ, Niehoff B (1996) Reproduction of the Arctic copepod Calanus hyperboreus in the Greenland Sea-field and laboratory observations. Polar Biol 16:209-219

Holmquist C (1970) The Genus Limnocalanus (Crustacea, Copepoda). Z Zool Syst Evolutionsforsch 8:273-296

Hove P van, Swadling KM, Gibson JAE, Belzile C, Vincent WF (2001) Farthest north lake and fjord populations of calanoid copepods Limnocalanus macrurus and Drepanopus bungei in the Canadian high Arctic. Polar Biol 24:303-307

Kates K, Volcani BE (1966) Lipid components of diatoms. Biochim Biophys Acta 116:264-278

Kattner G, Fricke HSG (1986) Simple gas-liquid chromatographic method for the simultaneous determination of fatty acids and alcohols in wax esters of marine organisms. J Chromatogr 361:263-268

Kattner G, Hagen W (1995) Polar herbivorous copepods-different pathways in lipid biosynthesis. ICES J Mar Sci 52:329-335

Kattner G, Krause M (1987) Changes in lipids during the development of Calanus finmarchicus s.l. from Copepodid I to adult. Mar Biol 96:511-518

Kattner G, Hirche HJ, Krause M (1989) Spatial variability in lipid composition of calanoid copepods from Fram Strait, the Arctic. Mar Biol 102:473-480

Kattner G, Hagen W, Graeve M, Albers C (1998) Exceptional lipids and fatty acids in the pteropod Clione limacina (Gastropoda) from both polar oceans. Mar Chem 61:219-228

Kosobokova KN, Hirche H-J (2000) Zooplankton distribution across the Lomonosov Ridge, Arctic Ocean: species inven- tory, biomass and vertical structure. Deep Sea Res I 47: 2029-2060

Kosobokova KN, Hanssen H, Hirche H-J, Knickmeier K (1998) Composition and distribution of zooplankton in the Laptev Sea and adjacent Nansen Basin during summer, 1993. Polar Biol 19:63-76

Larionov VV, Kodina LA (2000) Phytoplankton of the Ob and Yenisei transects. In: Stein R, Stepanets O (eds) Scientific Cruise Report of the Joint Russian-German Kara Sea Expedition of RV “Akademik Boris Petrov" in 1999. Ber Polarforsch $360: 36$

Lee RF (1975) Lipids of Arctic zooplankton. Comp Biochem Physiol 51B:263-266

Lischka S, Knickmeier K, Hagen, W (2001) Mesozooplankton assemblages in the shallow Arctic Laptev Sea in summer 1993 and autumn 1995. Polar Biol 24:186-199

Løvik JE (1979) Dyreplankton i Randsfjorden. Fauna 32:18-28

Pavlov VK, Pfirman SL (1995) Hydrographic structure and variability of the Kara Sea: implications for pollutant distribution. Deep Sea Res 42:1369-1390

Peterson BJ, Holmes RM, McClelland JW, Vörösmarty CJ, Lammers RB, Shiklomanov AI, Shiklomanov IA, Rahmstorf S (2002) Increasing river discharge to the Arctic Ocean. Science 298:2171-2173

Roff JC (1972) Aspects of the reproductive biology of the planktonic copepod Limnocalanus macrurus Sars. Crustaceana 22:155-160

Roff JC, Carter JCH (1972) Life cycle and seasonal abundance of the copepod Limnocalanus macrurus Sars in a high arctic lake. Limnol Oceanogr 17:363-370

Sargent JR, Henderson RJ (1986) Lipids. In: Corner EDS, O'Hara SCM (eds) The biological chemistry of marine copepods, vol 1. Clarendon, Oxford, pp 59-108

Sars GO (1903) An account of the Crustacea of Norway 4 , Copepoda Calanoida. Universitetsforlaget, Bergen

Scott CL, Kwasniewski S, Falk-Petersen S, Sargent JR (2002) Species differences, origins and functions of fatty alcohols and fatty acids in the wax esters and phospholipids of Calanus hyperboreus, C. glacialis and C. finmarchicus from Arctic waters. Mar Ecol Prog Ser 235:127-134

Stephansev L, Shmelkov B (2000) Brief characteristics and results from measurements of hydrophysical structures of waters in the estuaries of $\mathrm{Ob}$ and Yenisei. In: Stein R, Stephanets O (eds) Scientific Cruise Report of the Joint Russian-German Kara Sea Expedition of RV 'Akademik Boris Petrov' in 1999. Ber Polarforsch 360:8-19

Tande KS, Henderson RJ (1988) Lipid composition of copepodite stages and adult females of Calanus glacialis in Arctic waters of the Barents Sea. Polar Biol 8:333-339

Vanderploeg HA, Cavaletto JF, Liebig JR, Gardner WS (1998) Limnocalanus macrurus (Copepoda: Calanoida) retains a marine arctic lipid and life cycle strategy in Lake Michigan. J Plankton Res 20:1581-1597

Vinogradov ME, Shuskina EA, Lebedeva LP, Gagarin VI (1995a) Mesoplankton in the East Kara Sea and the Ob and Yenisey River estuaries. Oceanology 34:646-652

Vinogradov ME, Nikolaeva GG, Khoroshilov VS (1995b) The mesoplankton of the West Kara Sea and the Baidara Bay. Oceanology 34:653-660

Warren GJ (1985) Predaceous feeding habits of Limnocalanus macrurus. J Plankton Res 7:537-552 